\title{
Hajnal Zsolt
}

SZTE, Irodalom- és Kultúratudományok Doktori Iskola

\section{A merôlegesen viszonyuló vegyes állat: maszkulinitás, homoszexualitás és transzszexualitás metszéspontjai a kazovszkiji életmüben}

\section{A „normális” homoszexuális férfi tekintete a kazovszkiji oeuvre- ben}

Forgács Éva 1996-ban megjelent, ma már szinte beszerezhetetlen Kazovszkijmonográfiájában - amely egyébként Kazovszkij művészetének egyik legátfogóbb, minden kétséget kizáróan referenciaértékủ értelmezése mind a mai napig - tüpontosan mutat rá az építkezés Kazovszkij művészetében betöltött szerepének elsődleges jelentésére, funkciójára. Ez pedig nem más, mint „önmaga aprólékos, részletező, egyúttal nagyvonalú felépítése” (1996, 6). A kazovszkiji (emlék)művek ennek megfelelően egyértelműen az ipszeitás megszilárdítását szolgálják: a stabil középpontba, a (vala)Ki-vé projektálódó sub-jektum folytonosan rögzített pozíciójára, vagyis a „tervszerűségbe” (pro-jekt) való belevetettségére, valamint ennek a tervszerűségnek mint Törvénynek való alárendeltségére (sub) (Széplaky 2001, 245) emlékszik vissza. Az ebben az identitásképző folyamatban szerepet játszó emlékezés aktusa ugyanakkor annak a viszonyban-létben artikulálódó, a Másik számításba vételének felelôsségetikai gondolatával számoló szubjektivitásnak a létesülését hiúsítja meg, amely éppen az önmaga-felejtésen alapszik ${ }^{1}$. Az Én üregességének megtapasztalása a Máss(ágg)al való viszony-létben következik be: csakis valakivel való viszonyunkban fejeződünk ki valakiként; ez a valaki ugyanakkor csak akkor születik meg, ha egy másik által kilépünk önmagunkból, vagyis az (ön)azonosságból mint rögzített pozícióból. Ez a nyitott szubjektumot létesítő viszony: „ha kizökkenek a szubjektum halotti pózából” (Széplaky 2001, 382).

1 Széplaky szerint a viszonyban álló Én „legalapvetőbb képessége nem az önmagáravonatkozás, hanem az önmagán való túllépés, az önmagáról való elfelejtkezés. A felejtés nem a hanyatlás, a kihullás, az eltűnés, a „kevesebbé válás” értelmében merül fel, hanem úgy, mint a másság által szüntelenül újrateremtôdő identitás - újra és újra bekövetkező - alapítása. [...] A szubjektum a felejtés értelmét alkotó volttá-válás aktusa révén tud nyitottá válni az újat, a másságot hordozó jövő felé" (Széplaky 2011, 305). Jelen tanulmány terjedelmi (és tematikai) kerete(i) miatt nem részletezem a nyitott szubjektumra vonatkozó hosszas filozófiai fejtegetést, arról bővebben ld. Széplaky 2011, 301-359. 
Kazovszkij a squb-jektum ezen halotti pózait ismételte monomániásan vásznain: a viszonyban-lét (?) ott nem a Másikra való megnyílást és a vele való kiasztikus összefonódást hívta életre, hanem a „merőleges viszonyt”" , amely eredendően aszimmetrikus, mert hierarchikus, illetve preskriptív, mert „bejáratott” kulturális szkripte(ke)t játszik újra, vagyis nélkülözi az egyik identitásból a másikba való átjárásnak a hullámmozgását, amelyben helyet kaphatna a kölcsönös megelevenedés a másság megtapasztalásában. Egyáltalán: lehet-e a kazovszkiji merőleges viszonyt viszonynak nevezni? Nincs-e itt nyelvi pontatlanság, hiszen a ,viszony" eleve feltételezi a reciprocitást, a Kazovszkij képein megjelenített nexus viszont korántsem konszenzusos. A kazovszkiji terminus helyett helyesebbnek tartom a „merőleges viszonyulás” megnevezést, mivel abban jobban kifejeződik a magatartás egyoldalúsága. Pontosabban a tekintet egyoldalúsága, hiszen Kazovszkij alkotásainak nézôpontja a patriarchátus férfitekintetéé: ebben az eltárgyiasító optikában amely egyszersmind remek módon példázza, hogy a nemi binaritás intézményesülése sokkal inkább kulturális logikán, semmint a kromoszómák tudományán alapszik (Schilt 2010, 51) -, a(z általában nőnemú) Másik látványobjektummá, vizuális örömforrássá válik.

Szexuális eltárgyiasításnak nevezzük, amikor az aktor a Másikra (használható) tárgyként tekint szexuális örömszerzés céljából. Az eltárgyiasításnak rengeteg formája és módozata lehet, diverzitása széles skálán mozog: megnyilvánulhat a testek puszta esztétikai értékelésén át egészen a nemi erőszakig (Fischer et al. 1993). Látens, ugyanakkor ironikus módon valószínúleg éppen a leggyakoribb formája az eltárgyiasításnak az, amelyik a (kulturális) tekintet által történik meg (Kaschak 1992). Laura Mulvey Visual Pleasure and Narrative Cinema címú, 1975-ben megjelent, klasszikussá vált esszéjében használta először a „férfitekintet” (,male gaze”) terminust, hogy a nôk látványobjektummá válásának témáját beemelje a tudományos diskurzusba. A szexuális eltárgyiasítás elmélete összevethető a mulvey-i férfitekintet koncepciójával, hiszen az utóbbi szerint is tárggyá degradálódhat a Másik, ignorálva annak szingularitását. Fredrickson és Roberts egyetért abban, hogy a szexualizált tekintet az, ami lehetővé teszi a szexuális eltárgyiasítást, amikor pedig maga az eltárgyiasítás végbemegy, a testrészek válnak a Másik jelölóivé. Fredrickson és Roberts az eltárgyiasító tekintet három formáját különböztetik meg. Ebből a harmadikat Mulvey kutatásaira

${ }^{2}$ Kazovszkij úgy gondolta, hogy a kép síkja közte és a modell között húzódik, és hogy a kép nem síkban helyezkedik el, „hanem a néző és a tárgy közötti dinamikusan pulzáló aláfölérendeltségek mélységi játéka a valós térben” (Kazovszkij 2012, 203). A kép síkjának ezen elképzelése alapján a látósugár szubjektuma és a tárgy között, amit néz, hatalmi viszony áll fenn. Azt követően került a képekre a szubjektumjelölő „vegyes állat”, hogy Kazovszkij realizálta, rajta kívül senki nem nézi így az alkotásait. A vegyes állat szintén „merőlegesen viszonyul" az általa pásztázott idolokhoz, tehát eltárgyiasít. 
hivatkozva fogalmazzák meg, s azt az eltárgyiasító tekintetnek a vizuális médiával való találkozásának kapcsán jelölik ki. Testek és testrészek kerülnek a reflektorfénybe, amely fókuszáltság így implicite egy szexualizáló-szemlélői pozícióba helyezi a nézőket (Fredrickson \& Roberts 1997, 176). Hiba lenne azt hinni, hogy a férfitekintet pusztán a pornográfiára korlátozódik: a példaadó maszkulinitás (optikája) a legkülönbözőbb műfajú filmektől kezdve a televíziós músorokon át egészen a reklámokig, vagyis a kommersz populáris kultúra legtöbb műfajában tetten érhető (Connell 2012a, 278). Nincs ez másképp a magasmúvészet, például a kanonizált festészet berkein belül sem. Erre kitűnő példa El Kazovszkij vizuális múvészete, ami a férfitekintet és a szexuális eltárgyiasítás parabolájának is tekinthető.

Sem Mulvey, sem pedig Fredrickson és Roberts nem térnek ki arra, hogy a férfitekintet és a szexuális eltárgyiasítás hogyan is módosul(hat), amikor homoszexuális szubjektumok múködtetik azokat, de a kutatások szerint többnyire ezekben az esetekben is a férfiszubjektivitás heteronormatív és hegemón konstrukciói a mérvadók (Wood 2004, 54). Ebből következően a társadalmi nem határozza meg az eroticizmust is (Connell 2012a, 215). Mivel a férfiak legtöbbje párkeresés, párválasztás során a fizikai tulajdonságokra helyezi a hangsúlyt, azok, akik egy férfi figyelmét igyekeznek magukra felhívni, a társadalmi létezés során arra kondicionálódnak, hogy egy megfigyelő perspektívájából tekintsenek magukra, vagyis szexuális tárgyként. Mindebből logikusan következik, hogy a meleg férfiak nem csak cselekvői, hanem elszenvedői is az eltárgyiasításnak (Wood 2004). Ez a meleg férfitekintet ambivalenciája, és ebből is tisztán látszik, hogy alárendelt maszkulinitásuk és privatizált politikájuk ellenére a homoszexuális férfiak sem immunisak a patriarchátus destruktív hatásaira, az ô vágyaikat és magát a katexist is a társadalmi nemek fennálló rendje strukturálja (Connell 2012a, 215). Emiatt, továbbá túlnyomórészt maszkulin társadalmi jelenlétük, személyes kapcsolataik előtérbe helyezése, valamint a feminizmussal való szolidaritásuk hiánya miatt gondolja azt Connell, hogy korlátozott a meleg politika által előidézett társadalmi változás, kevéssé „provokálják” csak a társadalmi nemi rendet (Connell 1992, 748). A társadalmi nemek rendjének egésze a maszkulinitást egy konkrét hatalmi struktúrához, illetve a femininitás és maszkulinitás szembenállása által kifejezett különbözőség általános szimbolizmusához rendeli (Connell 2012a, 289). A domináns társadalmi narratívában a szubjektum-objektum reláció erősen „társadalmi nemesített”, amely disztribúcióban legtöbbször a férfiaknak adatott, adatik a szubjektum-, a nőknek pedig az objektum-státusz, ezért (is) látható a Kazovszkij-alkotások látványobjektumainak helyén filigrán, balerinaruhás, androgünnek ható (fiú)alakok, nem pedig mezomorf teltalkatú vagy éppen hipermaszkulin férfiak. 
Kazovszkij meleg maszkulinitását a hegemón keretrendszerhez igazította, vagyis az a társadalmi nemek világrendje szerint szerveződött. A társadalmi és kulturális normák külső stimulánsok, attraktorok, referenciapontok, amelyek mágnesként vonzzák a szubjektumot bizonyos irányokba. A társadalmi imaginárius így, Braidotti kifejezésével, mintegy „diszkurzív ragasztóként” funkcionál, amely szakaszos és ellentmondásos módon ugyan, de összeilleszti a fragmentált Ént (Braidotti 2002, 40). „Arra vágytam, hogy 'normális' homoszexuális férfi legyek" (Kazovszkij 2012, 236) - hangzott el Kazovszkij életének utolsó interjújában a sokatmondó kijelentés, elsőre egyenesen oximoronikusnak hatva, hiszen a bináris logika szerinti mindenkori norma és deviáció hogyan is kerülhetne ugyanarra a lételméleti alapra. Az idézőjelbe tett jelzőt ugyanakkor nem csak erre, a nyelvhasználatban is testet öltő értékítéletre vonatkoztathatjuk, hanem a szóban forgó kisebbség egy feltételezhetően valóban létező csoportjára, a csoportidentitás egy specifikus esetére. Hiszen az állítás nem egy akármilyen homoszexuális férfi ontológiai státuszára vonatkozott, hanem egy normális homoszexuális férfiéra. Ennek értelmében viszont akkor beszélhetünk normális és nem normális homoszexuális férfiakról. De mi teszi ezeket a homoszexuális férfiakat normálissá, normálisabbá a többi homoszexuális férfival szemben? A kérdés megválaszolásakor tanácsos mindvégig észben tartanunk, hogy a szubjektum nem más, mint a hatalom és a vágy különböző szintjei közötti konstans elmozdulás és alkudozás folyamata, az akaratlagos választások és tudattalan működések közötti állandó oszcillálás (Braidotti 2002, 75-76). A maszkulin társadalmi nem mint testre reflektáló praxis átcsatolásai mindenkor bonyolultak, távolról sem koherensek, sőt inherens módon ellentmondásosak, gyakorlásuk során pedig nem csupán individuális életek, hanem egy társas világ bontakozik ki (Connell 2012a, 102).

Mivel a patriarchális ideológiában a homoszexuális létforma többnyire megtestesíti mindazt, amit szimbolikusan kizártak a hegemón maszkulinitásból (Connell 2012a, 119), az „ideális maszkulinitás” eszméje miatt a homoszexuális férfiak a gender-konformitás érdekében a hegemón és heteronormatív maszkulinitások szerint konstruálhatják meg testet öltött szubjektumukat. Öket nevezi Connell „nagyon hetero meleg férfiak”-nak (Connell 1992, 746). Ezzel azonban egyúttal arra is késztetik magukat, hogy a „női(essége)t” mint olyat teljes egészében elutasítsák, s a jóváhagyott maszkulinitások (irreális) manifesztációit kultiválják, propagálják. A patriarchális társadalmi és családi struktúra stabilitására nézve nagyobb veszélyt jelent a férfi femininitás a női maszkulinitásnál (Halberstam 1998, 6), ezért is jobban tolerált a női gender-deviáció a férfinál. Mivel a köztudatban a férfi femininitás a melegség elsődleges jelölője, a homofób kulturális szkriptek azzal büntetik az effeminált jellegzetességeket mutató férfiakat, hogy 
megbélyegzik orientációjukat (Wood 2007, 54). Ezért is válik a maszkulinitás kollektív praxisa csoportszinten performansszá (Connell 2012a, 163). Fontos ugyanakkor kiemelni, hogy marginalizáció és jóváhagyás viszonya alárendelt maszkulinitások között is létrejöhet (Connell 2012a, 122). Ennek értelmében bizonyos meleg-maszkulinitások mint a társadalmi nemi viszonyok rendszerén belül létező gyakorlatok konfigurációi még az alárendelt csoporton belül is peremlétre szorulnak. Ezzel magyarázható, hogy a meleg társadalmi színtéren is pozitívabb fogadtatásban részesülnek egyes homoszexualitások a többieknél (Vidal-Ortiz 2002, 184): a nem maszkulin férfiak például ebben az esetben is alsóbbrendűeknek bizonyulhatnak azokkal a férfiakkal szemben, akik melegként így vagy úgy, de a heteropatriarchális maszkulinitás tradicionális esszenciáját testesítik meg (Wood 2007, 54). A homoszexualitás tényéből azonban nem egyenesen következik a maszkulinitásból való kirekesztés, ezeknek a férfiaknak szexualitásuk és férfi voltuk apropóján sokkal inkább strukturális természetű, a maszkulinitás(uk)ra irányuló konfliktusokkal kell számolniuk (Connell 1992, 737). Láthatjuk tehát, hogy a társadalmi nem strukturálisan szorosan kapcsolódik a különböző szexuális orientációk reprezentációjához (Vidal-Ortiz 2002, 184), valamint, hogy a melegek is hozzájárulnak a társadalmi nem kifejezésének korlátozásához (Vidal-Ortiz 2002, 219). A meleg férfitekintet akaratlanul lehetôvé teszi a társadalmi nemi markerrel jelölt (test)esztétikának nem csak, hogy egy sarkalatos dimenziót konstituáljon a meleg szubkulturális identitások konstrukciójában, de az erôviszonyokat is meghatározza mind a meleg szubközösségeken belül és között (Wood 2007, 57).

\section{A transzmaszkulinitások sajátosságai}

Maszkulinitás és homoszexualitás imént bemutatott kereszteződései alapján kijelenthető, hogy a homoszexuális férfiak kollektív tudásának szerves részét képezi „a társadalmi nemmel kapcsolatos bizonytalanság, a test és az identitás közötti feszültség, valamint a maszkulinitáson belüli és az azt övező ellentmondások" (Connell 2012a, 73). De mennyivel válik még ellentmondásosabbá ez a meleg maszkulinitás, ha történetesen egy nőnemú test aktiválja azt? Hogy a kérdés megválaszolásához közelebb kerülhessünk, először is engednünk kell két tudományág, a maszkulinitáskutatás és a transzstúdiumok - egyébként igen ritkán megvalósuló - dialógusának létrejöttét, mivel ezen kutatási területek halmozták fel azt az ismeretanyagot, amely a maszkulinitás(ok) multiplicitását tételezi.

Ezeket a maszkulinitásokat ezen vizsgálódások szituatív pozíciókként valószínúsít, amelyeket a legkülönfélébb fizikai testek képesek gyakorolni, ennek megfelelően pedig dekonstruálni a maszkulinitást mint olyat, amit az 
általános vélekedés „természetszerúleg” a férfitest produktumának tart. Connell szerint a férfiasság a társadalmi nemi gyakorlat egy konfigurációja, amely magukra a testekre reflektál, és semmiképpen sem a biológiai vagy társadalmi determinizmusból, vagy pedig a kettő kompromisszumából következik (2012a, 88). Connell elmélete a maszkulinitást olyan normák és ideológiák összességeként tematizálja, amely függetleníthető maguktól a férfitestektől. Ebből következően minden szubjektumot képesnek tart annak gyakorlására, tekintet nélkül kromoszomális nemére, társadalmi nemi pozicionáltságára, vagy éppen szexuális orientációjára. Legutóbbi munkáiban Connell amellett érvel, hogy a transzszexualitás nem csupán egy identitáskérdés, hanem anyagi és gyakorlati tapasztalatok, illetve előfeltételek sokasága (Connell 2012b, 864). Ennek megfelelően számottevő különbség van egy nagyvárosból és egy periférikus térségből származó transzszexuális esete között, hiszen a más-más kontextusba való beágyazottság rendszerint eltérő episztemológiát és ontológiát eredményez - már csak éppen ezért is (lenne) fontos dekolonizálni a transzmaszkulinitásokat, hiszen a társadalmi nemi gyakorlatok a gender-nonkonform megtestesülésekben - ami minimális mértékben pedig szinte az összes nőt és férfit érinti (Connell 2012, 867) lokálisan specifikusak, továbbá nemzeti és regionális kontextustól meghatározottak.

Jelen dolgozat vállalkozását tekintve a (transz)maszkulinitásra irányuló kutatások közül mindenképp kiemelendő Jack Judith Halberstam Female Masculinity címú, queer metodológiával megírt munkája, melyben sikeresen kapcsolja össze a maszkulinitás-kutatást a transz-stúdiumokkal. Halberstam egy queer, a társadalmi nemi konformitás hegemón modelljeit, így a bináris gender-rendszert sikeresen provokáló szubjektumpozíció feltérképezése által a „határjelenségek” pontosabb megértéséhez segít hozzá, miközben a női maszkulinitás koncepciójával Connellhez hasonlóan, de mégis egyedülálló módon destabilizálja a kapcsolatot férfiak és maszkulinitás között. Halberstam szerint a női maszkulinitás - ami még véletlenül sem a férfiasság valamiféle imitációjaként értendő - és az alternatív maszkulinitások teremtenek lehetőséget a maszkulinitást ab ovo a férfiléttől származtató, a ciszférfiak testének tulajdonító mítoszok és fantáziák felszámolására (Halberstam 1998, 4). Ezen hiedelmek egyébként még a cisznormatív tudományos hagyománnyal rendelkező maszkulinitás-kutatásban is vissza-visszaköszönnek. Halberstam felhívja rá a figyelmet, hogy a női maszkulinitás és a férfi femininitás mintája alapján megvan a veszélye, hogy újabb binárisokat hozzunk létre (Halberstam 1998, 28-29). ${ }^{3}$ Ezt mindenképp elkerülendőnek tartja, hiszen ezek a kisebbségi

3 Voltaképpen ugyanerre hívja fel a figyelmet Butler is a Gender Trouble 1999-es kiadásának előszójában, amikor arról ír, hogy a feminizmus nem idealizálhat bizonyos gender- 
maszkulinitások és femininitások önmagukban érvényesek. Halberstam munkája kivételesnek számít abból a szempontból, hogy a különféle szubjektivitások egymáshoz való viszonyában mutatja be a maszkulinitások multiplicitását: beszélhetünk olyan megtestesülésről, nevezetesen transznemű butchról, aki episztemológiai kereteként nem feltételezi a transzszexualitást, vagy ott vannak az FtM-ek (trannszszexuális férfiak) és a leszbikus butchok, akik esetenként társadalmi nemi normativitással vádol(hat)ják meg egymást, míg magát a stone butchot gyakorta csak a transzszexualitás egy tranzíciós fázisának tartják. Ezek az alternatív maszkulinitások kiváló viszonyítási és vonatkoztatási pontként szolgálnak a kazovszkiji életmüben dokumentált maszkulinitás vizsgálatához.

Salvador Vidal-Ortiz fenomenológiai megközelítésének tükrében úgy látja, hogy a transznemüek esetében a társadalmi nem, a biológiai nem és a szexualitás interakciójára vonatkozó vizsgálódások leginkább a transz nők („,male-to-female”, MtF) tapasztalataira fókuszáltak eddig, pedig a férfiasság társadalmi nemi konfigurációjának kollektív megértése szempontjából döntő fontosságú lenne a maszkulinitás tanulmányozása olyan egyének esetében is, akik úgy próbálnak teljes értékú életet élni a társadalmi mátrixban, hogy biológiai és társadalmi nemük között disszonancia áll fenn. Megannyi transznemű férfi számára a (heteropatriarchális) maszkulinitás a szubjektivitás elsődleges jelölője, ezért annak képzetei, fogalmai kulcsfontosságúak azok számára, akik a nőknek fenntartott pszicho- és szociokulturális teret szándékozzák akár teljességében, vagy csak részlegesen is, de elhagyni. VidalOrtiz osztja Henry Rubin azon nézetét, hogy a queer-elmélet a maga diszkurzív minőségében, amely a fragmentumokra, inkoherenciára, különbözőségre és transzgresszióra helyezi a hangsúlyt, komplexitásában képtelen megérteni és leírni a transzmegtestesülések szubjektív tapasztalatait, hiszen az esetenként megnyilvánuló stabilitás iránti igénnyel például nem tud mit kezdeni (Vidal-Ortiz 2002, 190). Maga a transznemúség is sok esetben egy meghaladandó állomás, amely a biztonságot nyújtó konkrét definíciók teréhez, az „otthon” trópusához vezet a biszexualitáshoz hasonló köztességből: a stabil társadalmi nemi identitás szilárd ontológiai talajként megelőlegezi a világgal való zavartalan kommunikációt és a világban való háborítatlan létezést. VidalOrtiz szerint a szexuális orientáció, a szexuális viselkedés, a vágy, a genderidentitás és a nemi kifejezés interszekciója a transzszexuális férfiak esetében különös komplexitással alakul (Vidal-Ortiz 2002, 224) - e bonyolult metszéspontok határozzák meg a kazovszkiji univerzumot is. Ahogyan azt a melegek kapcsán már megállapítottuk, a transzférfiak is elköteleződhetnek ugyan a hegemón maszkulinitás mellett, kifejezve ezzel egy homofób és/vagy

expressziókat az újabb hierarchiák kiépítése és a kirekesztés veszélye miatt. Ld. Butler 2002 [1999]. 
szexista társadalmi nemet, de ezek az attitűdök nem csupán az egyén személyes történetével magyarázhatók, hanem azzal az egyenlőtlen társadalmi nemi rendszerrel is (Vidal-Ortiz 2002, 221), amely az inkarnáció idejét és terét meghatározza.

Épp ezen rendszerbe való beágyazottságuk okán a transzférfiakat annak veszélye fenyegeti, hogy ama gender-konfigurációba esnek, amelyre a connelli terminológia csak alárendelt maszkulinitásként hivatkozik, s ami a melegséggel együtt a repozitóriuma mindannak, ami szimbolikusan kizáratik a hegemón maszkulinitásból. A hegemón maszkulinitásból való száműzetés mellett a másik leggyakoribb negatívum, ami a transzmegtestesülést érheti, az a radikális és/vagy materiális feminizmus felől érkező kritika. Néhány feminista teoretikus szerint a transzszexuális szubjektumok nemcsak, hogy nem törik meg a társadalmi nem bipolaritását, de (a nemi helyreállító mútéttel) megerősítik azt a biológiai és társadalmi nemre vonatkozó hegemón ideológiák elfogadásával (Raymond 1994, 85; Gurney 2004, 358).

Az egyik nem számára a másik nem tapasztalatai és megélt valósága mindig idegen marad. A férfiak, ellenére a transzszexuálisok fantáziáinak, sosem, még mútéti beavatkozással sem képesek érezni vagy megtapasztalni, milyen is nőnek lenni, nőként létezni. Legjobb esetben a transzszexuális képes megélni nőiességről szőtt fantáziáját - egy fantáziát, amit általában teljeséggel elcsúfitanak a felettébb nyers mútéti és kémiai beavatkozások. A transzszexuális nézhet ki úgy, mint egy nő, de sosem érezhet nőként vagy válhat azzá. (Grosz 1994, 207 - Ford. H. Zs.)

Bár Grosz a transz nóket teszi meg diskurzusa tárgyának, az ehhez hasonló érvelésekben a transzférfiak sem esnek más megítélés alá. Kristen Schilt a transzférfiak társadalmi létezésének sajátosságait vizsgálva kiemeli a társas, társadalmi férfiasság (,social maleness”) kivívásának fontosságát, ami a személyes férfiasság elismerését jelenti az interszubjektív kapcsolódások során:

A transzférfiak a társas férfiasságba való tranzíciójukat saját társadalmi nemi identitásuk különféle megközelítésével kezdik: természetes, változatos spektrum, alakítható ösvény. Ami összekötötte az általam meginterjúvolt férfiakat, az az arra irányuló vágy, hogy a mindennapi interakciók során társadalmilag ne nóként bánjanak velük. A hormonterápia, a mútétek és a ruházkodás segíteni tudnak ebben a folyamatban. [...] A társas férfiasság kivívása közben megnyilvánuló interakciós egyezkedések megvilágítják azt a kulturális folyamatot, ami alapjául szolgál a természetes különbözőségek sémáinak, valamint a különbözőség látszólag ártalmatlan képzetei mögötti hierarchikus hatalmi dinamikáknak. (Schilt 2011, 49 - Ford. H. Zs.) 
Schilt fejtegetéseiben tehát visszaköszön Vidal-Ortiz imént említett, a hegemón maszkulinitás melletti elköteleződésre vonatkozó pozíciója, miszerint az nem csupán egyéni intenció, hanem a szociális beágyazottság függvénye is. A társas férfiasság kivívása a transzférfiak számára korántsem egy egyszerü és sematikus folyamat, amely minden transzférfi számára egy meghatározott forgatókönyv szerint zajlik. Schilt, hogy homogenizálja a személyes társadalmi nemi identitások diverzitását, azokra a férfiakra, akik a testüket és megjelenésüket fizikailag a férfiasság standardjaihoz igazítják, olyan férfiakként utal, akik a társas férfiasságba tranzícionálnak (2011, 15). Bár Kazovszkij esetében testi átalakításról nem beszélhetünk, a társas férfiasság terminust mégis kulcsfontosságúnak tartom vele és művészetével kapcsolatban, hiszen az a meleg maszkulinitás áttételes, de folytonos megerősítése. A merőleges viszonyulást eredményező eltárgyiasító meleg férfitekintet kulturális genitáliaként a társas férfiasságot feltételező (hegemón) maszkulinitás egy „protézise”: a transz létezés fenomenológiájában kulcsfontosságú az az életesemény, amikor a társadalmi megítélés összhangba kerül az egyén régóta érzett, személyes férfitudatával, az tehát „egy lesz a srácok közül” (Schilt 2010, 174). Kazovszkij esetében ez azt a meleg férfiakból álló csoportot jelentette (volna), akikkel személyes elmondása szerint egy nyelvet beszélt: „Aztán felnőttkoromban találtam egy olyan csoportot; akiknek a nyelvét értettem, azok között a homoszexuális férfiak között, akik a fiatal fiúkat szerették” (Kazovszkij 2012, 55). Megtestesülésének specifikuma miatt viszont - és ennek ténye a transznemű vegyesség és a (születési) test státuszának komparatív elemzésekor lesz majd kiemelten fontos - itt sem volt teljes az egyezés: „De ebben a közösségben én nem is létezem, ember sem vagyok, mert egyik oldalon sem vagyok, egyszerüen nem is vagyok látható a szexus szempontjából” (Kazovszkij 2012, 56). Láthatjuk, hogy a maszkulinitás egyéni praxisa természetesen szükséges, de ahogyan arra már az előzőekben is utaltam, a maszkulinitásnak van egy kollektív dimenziója, azt a csoport is hordozza (Connell 2002, 153), relációk hálójából rajzolódik ki a társadalmi nem (Butler 2002 [1999], 13). Az, hogy a társadalmi nemi kompetencia elérésére tett személyes erőkifejtéseik során ezek a férfiak hogyan navigálnak a férfiak és nők közötti különbözőségeket kódoló kulturális jelrendszerekben, a maszkulinitás és a femininitás előfeltevéseiben, nem általánosítható.

\section{A nőies látványobjektum}

A társadalmi nemi hierarchia a transzszexuális férfiakra is éppúgy hatással van, mint a melegekre és a társadalom többi tagjára (Devor 1999, 608), mindez nyilvánvalóan vonta maga után Kazovszkij alkotásain a vágyobjektum „elnőiesítését” is. Ezzel magyarázható a balettnak, mint a közmegegyezés 
szerint erőteljesen női szcenikai jelenségnek és magának a balettruhának, mint identitásalkotó komponensnek a vizuális nyomatékosítása. A ruha identitás, szexualitás és társadalmi státusz szimbóluma (Abbott \& Sapsford 2001, 28), az uniformisviselés materiális praxisának pedig kiváltképp az a rendeltetése, hogy megakadályozza a normától való eltérést (Awasthi, 2017). Kazovszkij alkotásain a transznemú szubjektum által múködtetett meleg férfitekintet amely egyúttal rávilágít a nemi identifikáció anatómiai és kromoszomális referenseket nélkülöző lehetőségére (Vidal-Ortiz 2002, 198) - egyértelmúen egy képzetes balettelőadás „,néző vs. nézett” szerepdinamikájának megfelelően jeleníti meg az Én viszonyulását. Itt a férfi nem a tekintet általi levetkőztetéssel hajtja végre a szexuális eltárgyiasítást, hanem a felöltöztetéssel: a ruha a passzív látvány- és vágyobjektum mint a relációban megkövetelt Másik milyenségének és rendeltetésének indexeként funkcionál. A felruházott test tehát a hegemón maszkulinitás komplementaritásaként tárgyiasul, éppen ezért sem tartanám megalapozott értelmezôi lépésnek a Kazovszkij képein látható objektumpozíciót az internalizált (hetero)szexizmus és nőgyúlölet (Blumell \& Rodriguez 2020, 224) felől interpretálni, még ha a jelenség valós is, és a kultivációs elmélet értelmében a média szimbólumvilágának való ismételt expozíció (Gerbner \& Gross 1976, 193) eredményezte öneltárgyiasítás következtében bizonyos szubjektumok hozzá is járulhatnak a heteropatriarchális társadalmi struktúra fenntartásához.

„A fiúnak mindenképpen fiúnak kell lennie, aki eljátssza a lányt, tehát nem egy homoszexuális fiú, hanem egy fiú, aki szexualitásában megfelel annak az ideális nőképnek, amit én a XIX. századi irodalom vágyképeiből alkottam meg magamnak, a saját ideális férfiszerepem kiegészítójeként" (Kazovszkij 2012, 58 - mondta a „múlt századi stilizált férfitudattal” felnőtt Kazovszkij (2012, 33) vágyának mindenkori tárgyáról. Bár a Kazovszkij művészetét elemző, kanonizálttá vált megközelítések joggal hangsúlyozzák az antik görög kultúrának az oeuvre-ben való kitüntetett szerepét, egyes értelmezések azonban romantizálják azt az ógörögség azonos nemúek közti viszonyára vonatkozó feltételezett toleranciája miatt. A Kazovszkij képein látható viszonyulás kontextusában az antik görögség kulturális tradíciója nem a „szabad szerelem”, hanem a férfiak közti szexuális érintkezést is strukturáló, a társadalmi nemekhez rendelt aktív-passzív szerepleosztás dichotómiájának ténye (Karras 2000, 1255) miatt fontos. Nem tagadhatjuk, hogy a felfogás, miszerint csak a passzív, behatolást fogadó férfi a perverz, deviáns, minden kétséget kizáróan egészen napjainkig „sikeresen” megőrződött (Karras 2000, 2256): Chauncey az 1920-as évek New York-i melegéletével kapcsolatban írta le, hogy míg a homoszexuálisan aktív középosztálybeli férfiak szinte ugyanolyan szívesen játszottak mind passzív, mind aktív szerepet orális szex közben, addig a (korlátozott anyagi erőforrásaik okán marginalizált) 
munkásosztálybeli férfiak nagyobb része csak a normálisként elfogadott aktív, maszkulin szerepre korlátozta részvételét (1994, 119). Mind a mérsékelt, mind pedig az erôs társadalmi konstrukcionisták egyetértenek abban, hogy az antik görög (és római) kultúrában a társadalmi nemi aktív és passzív szerepek sokkal fontosabbak voltak magánál a tárgyválasztásnál (Karras 2000, 1255), mindezen tények összessége pedig, vagyis a szabad tárgyválasztással egybekötött konkrét társadalmi nemi szerepek termékeny identifikációs lehetőséget biztosítottak a kulturálisan érzékeny és adaptív Kazovszkij számára.

Forgács a szubjektum-objektum relációval kapcsolatban a következőket jegyzi meg:

E rendszerben mindenki egyszerre ura valaki más sorsának és kiszolgáltatott valaki másnak, vagy puszta helyzetéből adódóan, vagy a vágyai következtében. Olyan teátrális konstrukció áll előttünk, amelynek lehetséges dinamikáját eleve fékezi a determinációk rendszere: valamilyen irányból minden egyes szereplő meg van kötve (kötözve). (Forgács 1996, 17)

A vágyódó és a vágyott; a rab és őrzője, a szemlélő és cselekvő stb. felcserélhető szerepek, illetve a szimbolikus szereplők belső dialektikája mentén csúsznak a figurák egyik szerepből a másikba és vissza (Forgács 1996, 10-11).

Bár az imént említett szerepek valóban felcserélhetők, s az egyén adott helyzetétől függően feltünhet vagy az egyikben, vagy a másikban, Kazovszkij képeinek szereplőivel kapcsolatban ezt a relativitást hangsúlyozni alaptalan, hiszen a folytonosan ismétlődő alapszituáció jellegéből, vagyis az idol eltárgyiasításából következik az abban résztvevők pozíciójának rögzítettsége. Maga Forgács írja le, hogy a szépséget nem értelmezhetjük a morál vonatkozásában, így annak szubjektum feletti „hatalmát” - még ha az alkotó bevallása szerint a homoszexuális vonzalom szempontjából kulcsfontosságú is ${ }^{4}$ - sincs értelme a szerepfelcserélhetőség szempontjából vizsgálni: „A szépség legfőbb titka puszta léte: helyzete adott és nem kivívott. Tény és nem eredmény. Sem moralitáshoz, sem érdemekhez nincsen köz̨e" (Forgács 1996, 18. - Kiem. tőlem: H. Zs.). Az eltárgyiasító mindig az az életrajzi Én, az a transznemú meleg férfi, aki adoptálva a férfitestek heteronormatív konstrukcióit a hegemón maszkulinitás kontextusában, ezzel egyidejúleg elköteleződve egyfajta tradicionális, heteronormatív nemi érintkezés mellet, amely a szexuális öröm lehetséges forrásaként elsődlegesen a genitáliákat jelöli

${ }^{4}$ „A szépség. A férfiaknál a szépség és a szexualitás primer szinten összekapcsolódik. Az értékek között az első, hogy a fiúk milyen szépek, fiatalok, milyen a bőrük, a lábuk, hogyan mosolyognak" (Kazovszkij 2012, 56). 
ki (Courduriès 2006), pótló funkciójú fallikus tekintetével magáévá teszi az idolt. Az eltárgyiasított pedig mindig az a feminin homoszexuális férfi, aki a szubjektum kasztrációs szorongását oldó voyeurista és fetisisztikus tekintetében (Mulvey 1999, 840) a vágy tárgyaként, a hierarchikus viszonyulás szükségszerú komplementereként objektivizálódik. „,[...] amire vágytam, az ugyan egy mélységesen női lény, befogadó, lágy, a gyereklány és a fiatal nő közti keverék, a teljes befogadó barlang, anyai öl, de mindennek egy fiútestben, egy fiúszépségben kell megvalósulnia" (Kazovszkij 2012, 238) - láthatjuk, hogy a társadalmi nem által strukturált eroticizmus (Connell 1992, 748) nagyon hangsúlyos a kazovszkiji merőleges viszonyulás vonatkozásában. A fiatal férfiakhoz nem a hasonlóság, hanem a heteroszexuális különbözőség alapján viszonyult ${ }^{5}$.

Forgács Éva monográfiájának a már említett erényein kívül minden kétséget kizáróan egyik legnagyobb érdeme, hogy világosan kimondja, a megjelenített vágyobjektumok fétisek, a gyújtőszenvedélyú vándorállat játékszerei. Saját sablonjaikra redukált, határozott kontúrok közé fogott, jelzésszerû szereplők: egyrészt világosan felismerhető és azonosítható szimbólumok, másrészt jelentésük kontextustól függően változik, de „nem konkretizálódhatnak: sosem válhatnak teljesen egyértelművé és áttetszővé, hiszen mélyen mitologikus rétegekbe nyúló archetípusok, ellentétes princípiumokból összegyúrt sủrítmények" (Forgács 1996, 10-11).

Még mielőtt az idolok androgünitásának problémájához fordulnék, előtte pár mondatban kitérek az előbb idézett Forgács-passzusban olvasható archetípusok témájához, mivel az archetípusokra maga Kazovszkij is többször hivatkozott a vele készült interjúk során. A jungiánus elmélet szerint a kollektív tudattalan olyan univerzális és esszenciális igazságokat közvetítő archetípusokat, vagyis primordiális képeket, ősképeket tartalmaz, amelyek (pszichésen) vissza-visszatérnek, ismétlődnek a történelem folyamán. A jungi kollektív tudattalan mennyiségi sokaság egy egydimenziós és egyirányú rendszeren belül, nem pedig minőségi multiplicitás a komplexitások, sokrétűségek nyitott végú hálózatában (Braidotti 2002, 130). Forgács értelmezése - miszerint a Kazovszkij képein megjelenített vágyobjektumok archetípusok - referenciák és attribútumok szilárd keretén belül fixálja az idolokat és pozíciójukat ahelyett, hogy a férfi homoszexualitás speciális

5 „A hasonló, az azonos egyáltalán nem vonz. És ez még egy csavar: csak a másság vonz. Fiúra vágyom, mint idősebb férfi. Ugyanakkor legyen ő az anyukám, és ebben a viszonyban én kisgyerek vagyok. Anélkül vágyom a másik testi szépségére, hogy magamat testként élném meg. Az is fontos, hogy az elméleti gyerekszerelmek csakis lányok, nők voltak. [...] Ezek soha nem voltak valóságos nők. Hanem irodalmi alakok voltak. [...] Soha nem tetszett konkrét nő vagy lány. És amikor az első ember tetszett az általános iskola végén, akkor az fiú volt. Na de úgy viszonyultam ehhez a fiúhoz, mint Natasa Rosztovához Andrej Bolkonszkij, vagy Othello Desdemonához" (Kazovszkij 2012, 74). 
léttapasztalataiból, a meleg szubkultúrák müködési mechanizmusaiból „következtetné vissza” jelentésüket, vagy legalább a (nomád filozófiai gondolkodás jegyében) a percepció és immanencia kvalitatív átkeretezésére törekedne. Esszencializmusuk és a történelmi változás tényével szemben elfoglalt pozíciójuk teszik a jungi archetípusokat dogmatikus módszertanná (Braidotti 2002, 130). A látványobjektumokkal kapcsolatban ugyanannyira könnyelmű a „mitikus tudatot” és a mítoszok időtlenségét emlegetni, mint a „szabad szerelemmel” azonosított antik görögséget egyed(ül)i referenciapontként megjelölni a kazovszkiji magánmitológia, azon belül is az implicit homoerotika vizsgálata során. Fejtegetései folyamán Forgács később maga érvényteleníti archetipikus olvasatát, amikor a kazovszkiji szubkulturális és az antik össztársadalmi bálványozás téves azonosítása során az athéni idolok sablonsẓerüségéröl, vagyis csináltságáról nyilatkozik:

Ami Kazovszkij számára szubkulturális kultusz, s mint olyan is sokszorosan eltávolított, az Athénban, a magas kultúra legitim részeként, pontos ikonográfiai munkákat követő sablon volt. Amit Kazovszkij, minden explicit és verbális utalása mellett is - mint amilyenek, interjúi mellett, a Pierpaolo, Visconti feliratok egyes képeken - kódol és elrejt, az Athénban össztársadalmi kultusz tárgya volt. (Forgács 1996, 20)

A Kazovszkij képein bemutatott idolok a homoerotikus esztétikum historikus prototípusai, az ezekhez az idolokhoz való viszonyulás pedig a hegemón heteroszexuális mátrixban megvalósuló férfi homoszexualitás társadalmi gyakorlatának bizonyos logikája szerint narrálódik. Forgács szerint a legjelentősebb különbség Kazovszkij és a férfi homoszexualitás szépségeszményét megörökítő modern kori művészek, például Derek Jarman között az, hogy míg azok konkrét személyeket jelenítenek meg, addig Kazovszkijnál minden áttételessé válik, a manifeszt látenssé lesz. Ennek a látenciának éppen az idol prototipizálása az oka. A gyakorta tévesen szinonimaként használt archetípus és prototípus közötti különbséget a legszemléletesebben a prototípus materiális lényegiségével ragadhatjuk meg: a prototípus rendelkezik tényleges fizikai léttel, egy (szándékosan kreált) konkrét tárgy, míg az archetípus egy mitikus (idô)minőségen alapuló koncepció. A prototípusban visszaköszön a kapitalista fogyasztói attitűd, valamint a ki- és felcserélhetőség elve, amelyek Kazovszkij alkotásain a szubjektum viszonyulását meghatározzák. Prototipikus jellegükből adódóan Kazovszkij vágyobjektumai hangsúlyozottan mind ugyanolyanok, pedig a viszonyban-lét, az interszubjektivitás egyik felelősségetikai premisszája éppen a szinguláris iránti radikális és kivételes elköteleződés. Széplaky a következőképp ír erről: 
Amikor egy másik létezővel viszonyba kerülök, szükségszerűen kizárom a világomból az összes többit. A Másik választásának etikája azt jelenti, hogy abszolút egyediségemben odafordulok a Másik abszolút egyedisége felé. [...] Ám ez a radikális elköteleződés a Másik iránt egyben a többi másik, a végtelenül sok másik feláldozását jelenti: mindenki másnak a kizárását az éppen megképződő, abszolútnak tekintett, intenzív viszonyból. A radikális elköteleződés etikája - mint a Másikkal szembeni felelősségvállalás etikája így aztán egyfelől az egyetemes felelősség érvénytelenítésén, másfelől a másokkal szembeni erkölcsösség elvetésén alapul. [...] Az egyedi, véges létező egyszerre természetesen csak egyetlen másik létezőért vállalhat radikális értelemben felelősséget, mégpedig azért a másik kivételes létezőért, akivel éppen viszonyba kerül, aki iránt éppen elköteleződik. (Széplaky 2011, 407408)

Ha rátekintünk a Kis angyalok kara / Purgatórium 22. vagy a Cím nélkül (Kaszás párkáke) című képekre, azt láthatjuk, hogy a rajongó szubjektum előtt felsorakoznak a balettruhás, törékeny látványobjektumok.

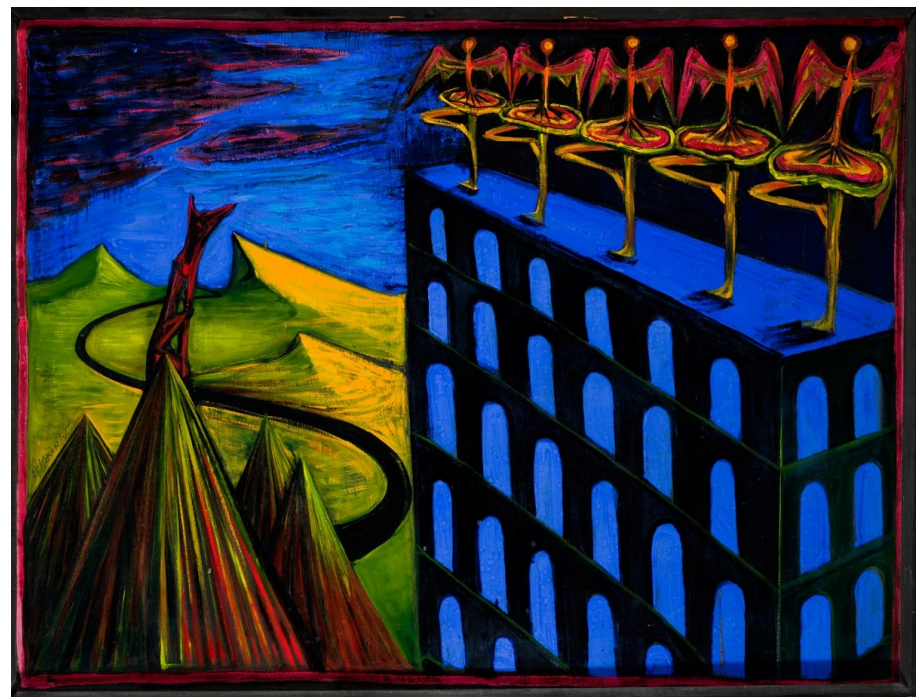

1. kép

Mindegyikük ugyanabban a testtartásban áll, és mindegyikük ugyanúgy néz ki. Akárha egy árutípus darabjai sorakoznának a futószalagon: csináltak, számtalanok, használhatók, helyettesíthetők. Nemcsak hogy a Másik abszolút egyediségéhez való odafordulás, illetve a multiplicitás kirekesztése nem történik meg a merőleges viszonyulás során, de ezen aktusok egzakt ellentétének evidenciája az, ami pornográf színezetűvé teszi e vágyképeket. A reprezentált szituációk (hús)piaci jellege azokat a portyázással egybekötött 
rövid idejű találkozókat idézik meg, amelyek, Connell szerint, a meleg szexualitásba való belépőt jelentik (Connell 1992, 745).

Forgács a torzó jelentéstartalmában az egyetemes szépség kifejezésének apropóján a nemi eldönthetetlenséget, így annak utalásjellegét tartja a legfontosabbnak:

Fiatal fiústesteket sejtető, voltaképpen androgin torzók ezek, minden égi és földi érzéki szépség koncentrátumai. Torzók, mert amit megtestesítenek, olyannyira érinthetetlen, hogy formájuk végig sem „mondható”. Nem tűri a festő kezének a közelségét. Mindig felsôtestek: általánosított, a nemi konkretizálást kerülő jelzések. A torzó: utalás, s elharapott, jelzésszerű formája lényegesen több feszültséget koncentrál, mintha pontosan kiírt, részletezett forma lenne. (Forgács 1996, 14)

Meglátásom szerint azonban a torzó éppen hogy a vágyobjektumot mint fétist egyértelműsíti azzal, hogy a komplex és egyedi Másik helyett a tor . Ö-t helyezi a figyelem középpontjába. Mindamellett, hogy az ábrázolt felsőtestek korántsem kerülik a nemi konkretizálást, hiszen egyértelmüen fiatal fiútest(rész)eket jelenítenek meg - még ha fiatalságuk okán fizikailag „éretleneket” is -, a testek fragmentált volta a ,szubjektumok” töredezettségét is kifejezi. A férfi néző tekintetében eltárgyiasult Másik (vágy)objektumként a szubjektummá válás lehetőségétől fosztatik meg, ontológiai alapja (testiszexuális) tárgyfunkciója. Ezt támasztják alá a festményeken látható arc nélküli vágyobjektumok is. A nyomtatott sajtóban tendencia, hogy a nőket testi fókuszáltsággal ábrázolják, s a közszemlére tett testrészek „,nem kapnak arcot” (Fredrickson \& Roberts 1997, 176). Hibás tehát Forgács azon következtetése, miszerint az idolok ,inkább csak kezdőbetűi, semmint megnevezései a vágy tárgyának” (1996, 14), továbbá, hogy „sem neme, sem puszta léte nem evidens: az idol a sivatag vándorának teremtménye” (1996, 14). (Jel)képi ábrázolása szempontjából a vágyódó szubjektum teremtménye, igen, szemantikája szempontjából viszont semmi esetre sem: meleg szubkulturális kód. Az androgünitás valóban valamiféle társadalmi nemi keveredést jelent ugyan, de ez Halberstam szerint csak ritkán vezet teljes ambiguitáshoz: ha valakit folyamatosan ellenkező nemünek hisznek, mint ami, akkor abban az esetben a szubjektum társadalmi nemi prezentációját nem az androgünitás, hanem az adott helyzettől függően vagy a maszkulinitás vagy pedig a feminitás jelöli $(1998,57)$. Az eltárgyiasítás iránti primer vágyat és intenciót, továbbá a homoszexuális viszonyulást strukturáló heteroszexuális különbözőséget az is kifejezi, hogy noha az idolok maguk hímneműek, alapjukként az európai kultúra passzív nőideáljai, többek között Csipkerózsika, Galathea és Coppelia szolgáltak (Forgács 1996, 26). 


\section{A kazovszkiji vándorállat és az otthon(ra találás) kérdése: A Halberstam-Prosser vita}

Forgács azzal folytatja a kazovszkiji építkezés jelentését taglaló gondolatmenetét, hogy az „építés, építkezés voltaképpeni célja „sors építése a sors folyamatos elbeszélése által" (1996, 6). A vegyes állat vagy másképpen vándorállat által narrált életmú mint a személyes sors lenyomata a privát rétegeken kívül a kulturális emlékezet építőköveiből rakódik össze. Ilyen építőkő ugye a görög mitológiai is, ami a kazovszkiji magánmitológia egyik primer forrása. Megjelenésének idején a Forgács-monográfia által kínált egyik legnagyobb értelmezői nóvum az volt, hogy a szépség homoerotikus kultuszának életmúbeli fontosságára hívta fel a figyelmet (Kazovszkij 2012, 137), amely kultusz épp annyira mélyen gyökerezik a Visconti-filmek melegség-reprezentációjában vagy éppen az operában, mint az ógörög kultúra pederasztikus hagyományában. A társadalmi nemi kompetencia elérése érdekében a transzférfiak rendszerint behatóan tanulmányozzák a maszkulinitás hegemón formáinak idealizált minőségeit (Schilt 2010, 52; Rubin 2003, 124). Voltaképpen ezt a „kutatómunkát”, kulturális otthonkeresést láthatjuk dokumentálódni a kazovszkiji sub-jektum mint „ontológiai terv” kulturális építóköveinek és a személyes rajongás tárgyainak (Bowie, Verlaine, Jarman, Napóleon stb.) folytonos reprezentációja során. Forgács szerint az

intenzív világépítés, amely Kazovszkij művészetének foglalata, két egymásnak ellentmondó szükségbőll fakad. Ezek egyike a világtól való függetlenség, szabadulás elérése, másika pedig az otthonra lelés, a világban való feloldódás vágya. Amikor Kazovszkij a megismerés kockáiból felépíti azt a világot, amelyben otthonra lel, helyet talál egy rendszeren belül, ez a rendszer azonban, egészében, elkülönül a világtól. (1996, 8)

Kár, hogy Forgács nem fejti ki, pontosan mire is vonatkozik, miben is nyilvánul meg ez a két, egymásnak ellentmondó szükség, a szabadulás és az otthonra találás vágya, mert ez az egyik kulcs a kazovszkiji vegyes állat, mint szubjektumjelölő pontosabb megértéséhez.

Halberstam már idézett Female Masculinity címú munkájában hosszasan reagál, polemizál Jay Prosser No Place Like Home: The Transgendered Narrative of Leslie Feinberg's „Stone Butch Blues” című, az otthon politikáját elemző írásában olvasottakkal, már csak azért is, mert Prosser Halberstam egy korábbi, F2M: The Making of Female Masculinity címú esszéjét jelöli meg a queer-elmélet transznemú megtestesülésre irányuló fixációjának elsődleges példájaként. Prosser szerint Halberstam a transzszexuális férfit a „kvírség” megtestesítőjének tartja (1995, 486). Prosser a könyvében három, jól 
elkülöníthető témára helyezi a hangsúlyt: először is a transznemü test queerelméleten belüli (félre)értelmezését taglalja mint a társadalmi nemi performativitás egy (vélt) privilegizált példáját; ezek után transzszexuális önéletrajzokon keresztül mutatja be az autobiográfia műfajának eklatáns eszközét az Én megkonstruálásában; majd az otthon politikájára tér ki, amelyen belül nézőpontja szerint a transzszexuális szubjektumok a kromoszomális és társadalmi nemük közötti koherenciára igyekeznek rátalálni. Prosser számára a „testnarratíva” az a történet, amelyet a transzszexuális a test köré sző, hogy az a test „olvashatóvá”, értelmezhetővé váljon (Prosser 1998, 101). Prosser úgy látja, hogy a radikálisan antinarratív queer-elmélet azért helyezi a hangsúlyt a transznemüek „határsértő magatartására”, hogy denaturalizálja a társadalmi nemet függetlenítve azt testi referenciájától (1995, 484). Értekezése során mindvégig kétkedő marad a transzneműséggel kapcsolatban, mivel annak genezisét a performativitás és transzgresszió posztmodern decentralizáltságában, megfoghatatlanságában látja. Éveléseiből kitűnik, hogy úgy véli, a queer határátlépések hontalanná teszik a transzszexuális szubjektumot. Amíg a queerek a határok lakhatatlan terében ünneplik a közöttiséget, addig a transzszexuálisok az otthon ígéretét kutatják. „A transzszexualitás - írja - az esszencialista konstrukcionizmus egy narratívája: célja, hogy rekonstruálja a húsos testet, hogy a szubjektum otthonosabbnak érezhesse megtestesülését" (Prosser 1995, 491 - Ford. H. Zs.). Vidal-Ortiz is amellett érvel, hogy nehéz elkerülni az esszencialista koncepciókat, mikor a társadalmi nemi binaritást újra és újra létrehozzuk a társadalmi mátrixunkban, amiben a különbözőségek számára egyébként sincsen tágasabb tér $(2002,220)$. A transzszexuális megtestesüléssel kapcsolatban Prosser legitimnek tartja a köztudatban is szilárdan státuszát tartó „rossz test” paradigmáját (Prosser 1998, 69), vagyis a szubjektum azon érzését, hogy rossz testbe született, nincs otthon saját testében.

Halberstam úgy gondolja, hogy a testi diszfória tapasztalata nem sajátítható ki a transzszexuális ontológiának, hiszen a transzvesztitáktól kezdve a drag queeneken át egészen a túlsúlyos emberekig sorolható azoknak a példái, akik valamiért nem érzik jól magukat a bőrükben. Halberstam szerint a hely, ahonnan az Én teorizálja, tematizálja az otthont, teljességgel képes felforgatni a társadalmi nem és a szexualitás modelljeit, ennek megfelelően például a transzszexuális férfi nézőpontjából a stone butch tranzíció előtt álló transzszexuális férfivá, a butch optikájából pedig a stone butch egy mütéti beavatkozást és hormonterápiát nélkülöző transzneművé lényegülhet (Halberstam 1998, 148). Bár Halberstam megjegyzése a különféle megtestesülések inkoherenciájára vonatkozó rövidlátást illetően valóban helytálló, azért az mégsem hagyható figyelmen kívül, hogy a diszfória intenzitása bizonyos esetekben milyen szélsőséges egzisztenciális 
állapotokhoz vezethet. Halberstam szerint való igaz, hogy valamennyi transzszexuális tranzícionál, hogy a kétértelműség földrajzát hátrahagyva otthonra találjon, de például számos operáción átesett transznő továbbra is a közöttiség területein tengeti mindennapjait, mivel személyes történetük láthatósága miatt képtelenek a passingra, azaz a cisznek túnésre; ezek az emberek pedig ott és úgy teremtenek otthont, ahol és ahogyan tudnak (Halberstam 1998, 163-164). Halberstam így folytatja gondolatmenetét:

Ha a határvidékek lakhatatlanok azon transzszexuálisok számára, akik úgy gondolják, hogy az otthon a határon túl várja óket, képzeljük csak el, miféle kihívást jelentenek azon szubjektumok számára, akik nem hiszik, hogy egy olyasféle otthon egyáltalán létezne, akár metaforikusan, akár szó szerint. Prosser társadalmi nemi kartográfiája a „,férfi” és a „női” hús határolta, mútét és endokrinológia szelte két területének hitén alapszik. A queer kartográfia, amit elutasít, a hibriditás feltérképezését preferálja: a queer hibriditás messze nem az a tündöklő és szédítő massza, aminek azt Prosser elképzeli, sokkal inkább az otthon vigasztaló, de tendenciózus képzeteibe való invesztálás veszélyeinek a felismerése. Egyes testek sosincsenek otthon, egyes testek egyszerủen képtelenek A-ból B-be jutni, egyes testek felismerik és együtt élnek az identitás inherens instabilitásával. (1998, 146 - Ford. H.Zs.)

A határvidéki létezésről és az otthonra találás intenciójáról Kazovszkij életmûve, élete és müve, ami esetében ,szoros, szétválaszthatatlan egységet képez" (Uhl 2015, 35), hiteles látleletet ad: emigráció, kétnyelvúség, „kétneműség”, női biológiai nem, múltszázadi stilizált férfitudat, homoszexuális orientáció, folytonos utazások, helykeresések. Credo IV. címú versében írja: „Sem ottani, sem itteni nem vagyok. / Nem áttelepült valahonnan. / [...] / Hagyják, hogy énem újraszülessék. I Próbálkoztam, hogy önmagam legyek." (Kazovszkij 2011, 7). A Leningrád 1972-ben így fogalmaz: „Ha sæegról-végról is, de csak olyat / Adj, ami otthonos" (Kazovszkij 2011, 81). Bármennyire fontos szerepet is tulajdonítsunk a kazovszkiji életmű kapcsán a fluiditásnak, és bármilyen interpretációs lehetőséget is tartsunk relevánsnak az oeuvre e szegmense kapcsán, afölött a tény fölött semmiképp sem hunyhatunk szemet, hogy a társadalmi nemek világrendjében inkarnálódó szubjektumot az „elfogadható módon való létezés”, a fizikai test, a személyes és a szociális társadalmi nem közti megfelelés és érthetôség a koherencia tapasztalatának csöppet sem csekély mértékű örömével képes megajándékozni (Schilt 2010, 174). A festményeken toposz-szerűen jelennek meg újra és újra a hosszú, néhol a hegyek közé vesző, máshol a Párkák sorsfonalában kirajzolódó, kacskaringós utak. Egy sorozat címe: Téli utazás. A binaritást szimbolizáló mérlegserpenyőkben vegyes állatok utaznak. Egy egész falka: a maszkulinitást a csoport hordozza (Connell 2002a, 153). Az utazás nemcsak hogy gyakori, de egyenesen kikerülhetetlen metafora a transzszexualitásról szóló 
diskurzusokban - ebből a szempontból a kazovszkiji testnarratíva kifejezetten hagyománykövető. Az Én-jelölő vegyes állat a test történetén keresztül narrálja a személyes sorsot, magát a sub-jektumot leíró, elbeszélő képeket, amik képregényként összeolvashatók. A kazovszkiji testnarratíva, a vegyes állat, és a személyes ontológiában szerepet játszó fluiditás és rögzítettség státuszának megértéséhez vegyük figyelembe, hogy a transzszexualitás mind a társadalmi nemi transzgresszió, mind pedig a társadalmi nemi konzervativizmus jelölője (Halberstam 1998, 160). Meglátásom szerint Kazovszkij képein a Bolygó Hollandi vegyes állatként kódolt Én csak a kulturális érthetôség vonatkozásában marginális vegyességtől kívánna szabadulni, az ambivalens „hímnősségtől”, a nemi diszfóriától: ez otthontalanságának oka. Maga Schilt is „vándor életekként” („unsettled lives”) (2010, 60) írja le a transzneműek férfi/nő bináris párja közti átjárását, Connell pedig a letelepedés megvalósítására („,to achieve settlement”) tett kísérletként a tranzíciót (2012b, 868). A vegyesség, a „köztes nem”, a decentralizáltság akceptálása, ünneplése szolgálhatott volna a társadalmi nemi binaritás elutasításának politikai tetteként, de a kazovszkiji Ént, vagyis a transznemúségétől vegyes állatot egy olyan férfiszubjektivitás fenomenológiai tapasztalatának vágya strukturálta, amely, még ha homoszexualitása miatt bizonyos vonatkozásban alárendelt is, de jelentős részt kap a patriarchális osztalékból.

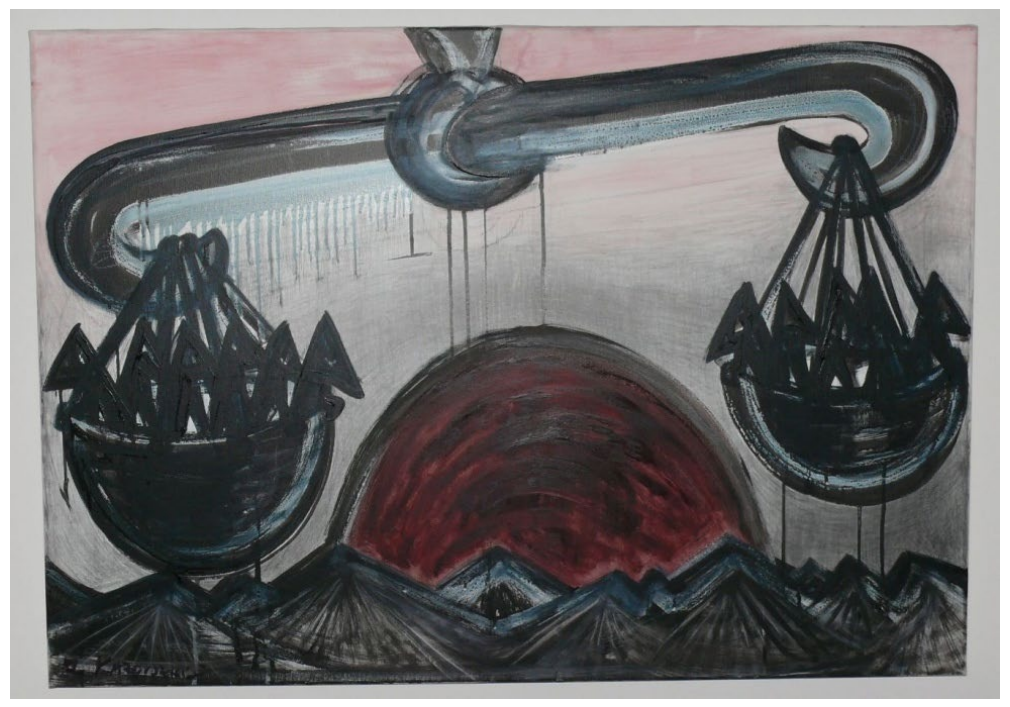

2. kép

Forgács szerint Kazovszkij alkotásai „mindig ugyanannak az alapélménynek az erőteljes, sűrű megfogalmazásai” (1996, 16) - véleményem szerint ez az az alapélmény. Emiatt is tartom a Forgács-féle interpretáció egyik legkifogásolhatóbb és leggyengébb pontjának a vegyesség és átjárhatóság, így 
az eldönt(het)etlenség méltatását, továbbá ezen átmenetiséget valószínűsítő jellegzetességek emancipációs lehetőséggel bíró ontológiai alapként való pozícionálását. „Kazovszkij múveiben a születésre adott szerepmeghatározottságok eltörölhetők és áthághatók" (Forgács 1996, 11-12) - írja Forgács. Igaza van, mert a Kazovszkij alkotásain látható szereplők meghatározottságaik, „másságuk” tényének következtében valóban „átmeneti lényeknek" bizonyulnak a heteroszexuális mátrix ${ }^{6}$ értelmezési keretében, puszta létezésükkel tehát ab ovo áthágják a társadalmi nemek világrendjét, továbbá a születésre adott szerep-meghatározásokat, vagyis a női és férfi nemi szerepeket is valóban képesek szubverzív potenciállal megközelíteni. Ezt bizonyítja az objektum „balerinasága” és maga a merőleges viszonyulás is, ugyanakkor a reprezentált szubjektivitás értékelése során magukat a nemi szerepeket semmiképpen sem lett volna szabad a nemi identitástól és a biológiai testtôl függetlenül, önmagában hangsúlyozni, hiszen a nemi identitás és a biológiai nem közti inkoherencia az, amiből a szubjektum ontológia bizonytalanságérzete elsődlegesen fakad. Ezen az inkoherencián az áthágható nemi szerepek lehetősége sem enyhít, hovatovább a nemi szerepről, mint megközelítésről már Connell is megállapította, hogy alapjaiban meddő (2012a, 57). Kazovszkij nem tartozott azok közé a transznemúek közé, akik a társadalmi nemre transzformatív potenciállal rendelkező fogalomként tekintettek, pedig ennek feltételezését indokolná a személyes életút, hiszen a genderqueerek, a nem bináris nemi identitással rendelkezők azok, akik a legkevesebb érdeklődést fejeznek ki a radikális testi átalakítások iránt (Schilt 2010, 44). ,[...] csak a másik nemben tudnék élni” (Kazovszkij 2012, 231) mondta Kazovszkij Rádai Eszternek. A „rossz test” tradicionális transzszexuális narratívájában (Lane 2009, 139) az ellenkező nem testi valósága, natív teste ontológiai referenciaponttá válik - ahogy Kazovszkij esetében is azzá vált.

Henry Rubin szerint a transzférfiak szubjektivitásában a hegemón maszkulinitás, és az annak való megfelelni akarás fontos szervezőerő: „Elég erősek, magasak, férfiasak? Nyakkendőket és zakókat kell viselniük, hogy férfiak lehessenek? Mi teszi az igazi férfit, és vajon lesznek-e valaha is igazik?” (Rubin 2003, 124 - Ford. H. Zs.). „Mi a maszkulinitás?” (Halberstam 1998, 1 - Ford. H. Zs.) - kérdezi Halberstam is könyve nyitómondatában. Amíg a feminizmus új lehetőségeket teremtett a női létezés megnyilvánulásának, addig

${ }^{6}$ A heteroszexuális mátrix Judith Butler terminusa, amellyel Monique Wittig „heteroszexuális szerződés” (heterosexual contract) és Adrienne Rich „kötelező heteroszexualitás” (compulsory heterosexuality) fogalmainak apropóján a kulturális érthetőség rendszerét szándékozza leírni. Butler szerint a testi koherencia és érthetőség érdekében stabil társadalmi nemen keresztül kifejezett stabil biológiai nem szükséges, ami aztán a kötelező heteroszexualitás gyakorlatán át ellentétesen és hierarchikusan definiálódik (Butler 2002 [1999], 194). 
a hegemón maszkulinitás továbbra is tartja szükre szabott kereteit a férfiak társadalmi létezése körül. Úgy tűnik, amíg a nőként való létezés, a nôvé válás a létezés puszta ténye által megvalósítható, addig a férfiasság folytonos teljesítmény eredménye (Chodorow 1989, 33). A férfi teste, legyen az egy meleg, transznemü, vagy akár transzszexuális férfi teste is, minden esetben a maszkulinitás kivívásáért, bizonyításáért és jóváhagyásáért folytatott harc csatatere (Schilt 2010, 164). A hegemón maszkulinitás kontextusában mutatkozik meg talán legegyértelműbben a szégyen szocializációs hatása: morális érzésként a szociális normákat társadalmasítja (Fredrickson \& Roberts 1997, 181-182). A kazovszkiji testnarratíva számára a normális homoszexuális férfit a cisznemü férfiszubjektivitás is teszi, annak az egy esszenciális indexe, hiszen általa élhető át a szexuális eltárgyiasítás, a behatolás maszkulinitást egyértelműsítő fenomenológiai tapasztalatának érzéki intenzitása. Az orientáció ebben a szubjektivitásban éppen ezért is különösen fontos: ahogyan az már megállapításra került, a meleg férfiak elköteleződhetnek egyfajta heteronormatív nemi érintkezés mellet, amely a genitáliákat tekinti elsődleges nemi örömforrásnak. A kazovszkiji vegyes állat szemléletes parabolája annak a ténynek, hogy a transzszexualitás nem csupán a jelentések sokaságától, de az egymásnak ellentmondó és egymással küzdő diskurzusok súlyától is terhes (Halberstam 1998, 165). A hegemón maszkulinitás a vegyes állat esetében érvénytelenítette a férfi megtestesülés szomatikus alternatíváit: ironikus módon a (transz)férfi inkarnáció azért maradt mindvégig imaginárius, mert a megszokott transzszexuális testnarratívákkal ${ }^{7}$ ellentétben a szimbólum itt nem aratott diadalt a hús felett (Connell 2012a, 96), az agnózia ${ }^{8}$ nem írta fölül a biológiai realitást (Rubin 2003, 151). Hogy az elemzett szubjektivitás esetén nem a transzgresszió, az immateriális fluiditás az Én elsődleges ontológiai referense, azt mi sem bizonyítja jobban, hogy nem érvényesül vonatkozásában Prosser azon, a társadalmi nem queer értelmezésével kapcsolatban tett kijelentése, hogy a biológiai test megszűnik eredetté, kiindulóponttá válni (Prosser 1995, 484). A kazovszkiji életmüben tematizált otthonra találás,

\footnotetext{
${ }^{7}$ Connell szerint számtalan transzszexuális testnarratíva létezik (2012b, 867).

8 Rubin a genealógiai mellett fenomenológiai módszerrel vizsgálja a transzszexuális megtestesülést. Szerinte a fenomenológia egy olyan értelmezési keret, amely képes hitelesen interpretálni a transzszexuális életprojekteket. Az agnózia idegenség-érzést eredményez: a test sajátként való megélése nem következik be. Merleau-Ponty elméletei alapján a transzszexuálisok agnóziásoknak tekinthetők, akik képtelenek a saját testük bizonyos részeit a sajátjukként érzékelni. Rubin szerint olyan testek nélkül, melyek adekvát módon fejeznék ki tulajdonosaik valódi identitását, a transzszexuálisok az agnóziás állapot kényelmetlenségével kénytelenek együtt élni.
} 
hazatérés tehát semmi esetre sem valami posztgender utópiában ${ }^{9}$ valósulhatott volna meg, hanem a cisznemú, homoszexuális férfi testiségének fenomenológiai tapasztalatában.

\section{Felhasznált irodalom}

Abbott, Pamela \& Francesca Sapsford. 2001. „Young Women and their Wardrobe.” In Ali Guy, Eileen Green \& Maura Banim (eds.) Through the Wardrobe. Women's Relationships With Their Clothes. Oxford - New York: Berg, 21-37.

Awasthi, Bhuvanesh. 2017. „From Attire to Assault: Clothing, Objectification, and De-humanization - A Possible Prelude to Sexual Violence?" Frontiers in Psychology 8: 338. Letöltés: 2021. január 20.

Blumell, L.E. \& Nathian Shae Rodriguez. 2020. „Ambivalent Sexism and Gay Men in the US and UK." Sexuality \& Culture 24 (1): 209-229. Letöltés: 2021. január 20.

Braidotti, Rosi. 2002. Metamorphoses. Towards a Materialist Theory of Becoming. Cambridge: Polity Press.

Butler, Judith. 2002 [1999]. Gender Trouble. New York: Routledge.

Chauncey, George. 1994. Gay New York: Gender, Urban Culture, and the Making of the Gay Male World, 1890-1940. New York: Basic Books.

Chodorow, Nancy. 1989. Feminism and Psychoanalytic Theory. New Haven, CT: Yale University Press.

Connell, R. W. 1992. „A very straight gay: Masculinity, homosexual experience, and the dynamics of gender." American Sociological Review, 57 (6): 735-51.

— 2012a. Férfiak. Eltünö szerepeke. Ford. Dudik Annamária Éva. Budapest: Noran Libro.

— 2012b. „Transsexual Women and Feminist Thought: Toward New Understanding and New Politics." Signs 37 (4): 857-81.

Courduriès, Jérôme. 2006. „Gay Couples and the Norm of Conjugal Equality." Ethnologie française 36 (4): 705-711. Letöltés: 2021. január 20.

${ }^{9}$ Az alternatív maszkulinitások és femininitások megnyilvánulásának specifikációjára irányuló igényben egy posztgender társadalomhoz való közeledésünk jelei fedezhetők fel (Schilt 2011, 172). 
Devor, Aaron. 2016 [1997]. FTM: Female-to-Male Transsexuals in Society. Bloomington: Indiana University Press.

Fischer, Karla, Neil Vidmar \& Rene Ellis. 1993. „The culture of battering and the role of mediation in domestic violence cases." SMU Law Review 46 (5): 2117-2174. Letöltés: 2021. január 20.

Forgács Éva. 1996. El Kąovsqkij. Budapest: Új Művészet Kiadó.

Fredrickson, Barbara L. \& Tomi-Ann Roberts. 1997. „Objectification Theory: Toward Understanding Women's Lived Experiences and Mental Health Risks." Psychology of Women Quarterly 21 (2): 173-206. Letöltés: 2021. január 20.

Gerbner, George \& Larry Gross. 1976. „Living with Television: The Violence Profile." Journal of Communication 26 (2): 173-199.

Grosz, Elizabeth. 1994. Volatile Bodies: Toward a Corporeal Feminism. Bloomington - Indianapolis: Indiana UP.

Gurney, Karen. 2004. "Twisting the Knife - Discrimination in the Law." Deakin Law Review 9 (2): 339-363. Letöltés: 2021. január 20.

Halberstam, Judith. 1998. Female Masculinity. Durham: Duke University Press. 1999. „F2M: The Making of Female Masculinity.” In Janet Price \& Margrit Shildrick (eds.) Feminist Theory and the Body: A Reader. New York: Routledge, 125-133.

Hines, Sally. 2010. „Introduction.” In Sally Hines \& Tam Sanger (eds.) Transgender Identities. Towards a Social Analysis of Gender Diversity. New York: Routledge, 1-22.

Karras, Ruth Mazo. 2000. „Active/Passive, Acts/Passions: Greek and Roman Sexualities." The American Historical Review 105 (4): 1250-1265. Letöltés: 2021. január 20.

Kaschak, Ellyn. 1992. Engendered lives: A new psychology of women's experience. New York: Basic.

Kazovszkij, El. 2011. Homokšö̋oókút - Versek. Margócsy István (vál.). Budapest: Magvető.

„A csendélet színpadai - El Kazovszkijjal beszélget Rényi András.” In Cserjés Katalin \& Uhl Gabriella (szerk.) Látáscsapda-Besqélgetések El Kazovsqkijjal. Budapest: Magvető, 202-211.

—_ „Arra vágytam, hogy 'normális' homoszexuális férfi legyek” - E1 Kazovszkij képzőművésszel Rádai Eszter készített interjút In Cserjés 
Katalin \& Uhl Gabriella (szerk.) Látáscsapda - Beszélgetések El Kazousžkijjal. Budapest: Magvető, 225-243.

2012. Az elveszett nyelv - Kristóf Attila interjúja In Cserjés Katalin \&

Uhl Gabriella (szerk.) Látáscsapda - Beszélgetések El Kazovszkiijjal. Budapest: Magvető, 29-35.

2012. Kutya és kötél - El Kazovszkijjal beszélget Bartis Attila és Dékei

Krisztina a Sivatagi Homokozó bejáratánál In Cserjés Katalin \& Uhl

Gabriella (szerk.) Látáscsapda - Beszélgetések El Kazouszkiijjal. Budapest: Magvető, 36-45.

2012. „Múlt századi stilizált férfitudattal nőttem fel” - Két beszélgetés

El Kazovszkijjal (Kalmár Melinda, Ungváry Rudolf) In Cserjés Katalin \& Uhl Gabriella (szerk.) Látáscsapda - Beszélgetések El Kazovszikijjal. Budapest: Magvető, 46-79.

2012. „Unalmas, ha mindig meg kell valósítani az elképzeltet” - El Kazovszkij képzőmúvésszel beszélget Szikszai Károly In Cserjés Katalin \& Uhl Gabriella (szerk.) Látáscsapda - Beszélgetések El Kazovs₹kijjal. Budapest: Magvető, 136-144.

Lane, Riki. 2009. „Trans and Bodily Becoming: Rethinking the Biological as Diversity, Not Dichotomy." Hypathia 24 (3): 136-157. Letöltés: 2021. január 20.

Mulvey, Laura. 1999. „Visual Pleasure and Narrative Cinema.” In Leo Braudy \& Marshall Cohen (eds.) Film Theory and Criticism: Introductory Readings. New York: Oxford UP, 833-844.

Prosser, Jay. 1995. „No Place Like Home: The Transgendered Narrative Of Leslie Feinberg's 'Stone Butch Blues." Modern Fiction Studies 41 (3/4): 483-514.

— 1998. Second Skins: The Body Narratives of Transsexuality. New York: Columbia University Press.

Raymond, Janice. 1994 [1979]. The Transsexual Empire. The Making of the SheMale. New York: Teachers College Press.

Rubin, Henry. 2003. Self-Made Men: Identity and Embodiment among Transsexual Men. Nashville, Tennessee: Vanderbilt University Press.

Schilt, Kristen. 2010. Just One of the Guys? Transgender Men and the Persistence of Gender Inequality. Chicago, London: The University of Chicago Press.

Széplaky Gerda. 2011. Az, ember teste. Filozófiai irások. Pozsony: Kalligram. 
Uhl Gabriella. 2015. „Identitás-shock. A többszörös identitás megjelenése El Kazovszkij müvészetében." In Cserjés Katalin \& Szauter Dóra (szerk.) Meröleges viszonyok. Tanulmányok El Kazovszkijról. Szeged: JatePress, 32-37.

Vidal-Ortiz, Salvador. 2002. „Queering sexuality and doing gender: Transgender men's identification with gender and sexuality." In Patricia Gagné \& Richard Tewksbury (eds.) Advances in Gender Research 6. Gendered Sexualities. Bingley: Emerald Group Publishing Ltd., 181233.

Wood, Mitchell. 2004. „The Gay Male Gaze: Body Image Disturbance and Gender Oppression Among Gay Men.” Journal of Gay \& Lesbian Social Services 17 (2): 43-62.

\section{Müalkotások}

Kazovszkij, El. 1992. Kis angyalok kara. Purgatórium XXII. Olaj funérlemez. 112 x 148 cm. Budapest: Szalóky-gyüjtemény. Letöltés: 2021. január 20.

Kazovszki, El. 2006. Téli utazás XV. Téli napforduló III. Olaj vászon. 70 x 100 cm. Győr: Dr. Nagy Miklós gyüjteménye. Letöltés: 2021. január 20. 